\title{
Abstracts
}

\author{
Werner Reutter
}

\section{Democracy and Federalism}

Two Constitutional Principles and Their Relationship With Each Other

The relationship between democracy and federalism is a controversial issue in political science. The German case shows that two features characterize the respective debate: truncations and references to varying democratic theories. Thus, "refederalization" cannot per se be regarded as more democratic than the status quo ante, as many simply postulated in order to push forward the reform of German federalism. In contrast to what many had postulated, it rather has to be pointed out that the contradictions or the incompatibilities between democracy and federalism are merely tensions that are inherent to democracies and not to be dissolved.

\section{Philip Manow}

\section{Disproportionality and Its Consequences Candidate Vote in Germany's Mixed-electoral System}

The article analyzes how candidate vote are translated into district seats in the plurality tier of Germany's mixed-electoral system. In particular it addresses the question of disproportionality. The article highlights the consequences of disproportionality for the internal composition of the parliamentary parties, for parties' nomination strategies and for the probability that so-called overhang mandates occur. 


\section{Mathias Maas}

\section{The Value of Military Interventions for Intrastate Conflict Resolution A Statistical Analysis for the Time Between 1989 and 2006}

Theoretically the ability of an intervening actor to end a conflict depends on its capacities to manipulate the decisionmaking process of the warring parties through coercive measures and to establish the socioeconomic and political structures for long-term peace. An analysis of the period between 1989 and 2006 using logistic regression shows that the number of intervention troops, the intervention strategy, actual defensive intervention activities as well as interventions by the UN significantly influence the chance to end a violent conflict, while the power capabilities of the intervening actors as measured by the Composite Index of National Capabilities as well as non-UN interventions do not make a difference.

\section{Eva Krick}

\section{Governance with Summits - The Grand Coalition's Advisory Committees}

While the red-green coalition was known for using so called 'commissions' as instruments of governance, the grand coalition introduced a new form of advisory committee - the summit of 'experts'. Starting from research on commissions, this article asks what kind of organisation these summits are, in which way they differ from commissions and which purposes they are supposed to fulfil from the perspective of government. The findings are based on an empirical study about the 'IT-summit' and the 'integration summit'. It will be shown that summits are not used for breaking decision traps. Rather, the function of presenting politics to the public is dominant and accompanied by two other gains: shifting awareness by raising the value of a political issue and societal self-governance, which draws on private resources. 